\title{
Determination of haloperidol drug in ampoules and in urine samples using a potentiometric PVC-membrane and graphite coated wire electrodes
}

Hazem M. Abu SHAWİSH, Hassan TAMOUS, Asma A. SHAHEEN, Khaled I. Abed ALMONEM, Ahmed Awad ELGAMEL, Wael S. AL-LHAM

\section{ABSTRACT}

A new PVC membrane, called sensor $\mathrm{P}$, and graphite coated wire, called sensor g, for haloperidol drug (HP) are described. The electrodes $\mathrm{P}$ and $\mathrm{C}$ exhibit a Nernstian slope of $57.4 \pm 0.8$ and $61.1 \pm 0.4 \mathrm{mV}$ per decade over a wide concentration range from $3.7 \times 10^{-6}-1.0 \times 10^{-2} \mathrm{~mol} / \mathrm{L}$ and $5.8 \times 10^{-7}-1.0 \times 10^{-2} \mathrm{~mol} / \mathrm{L}$ and the limit of detection (LOD) of $1.6 \times 10^{-6} \mathrm{~mol} / \mathrm{L}$ and $4.2 \times 10^{-7}$ $\mathrm{mol} / \mathrm{L}$ over the $\mathrm{pH}$ range of $2.5-7.5$ and 2.5-8.0 respectively. The presented sensors show a very good selectivity for HP drug over the common interfering chemical species. The proposed electrodes were successfully used for determination of HP drug in ampoules and in urine samples with satisfactory results.

Keywords: Potentiometry; Haloperidol drug; coated wire electrode; PVC membranes electrode; Ion-selective electrode.
Hazem M. Abu Shawish

Chemistry Department, College of Sciences, Al-Aqsa University, Gaza, Palestine.

Hassan Tamous

Chemistry Department, Al-Azhar University, Gaza, Palestine

Asma A. Shaheen

Pharmacy College, University of Palestine

Khaled I. Abed Almonem

Health Professions, University College of Applied Science, Gaza, Palestine

Ahmed Awad Elgamel

Institute of Forensic Evidence Sciences, the National Ribat University, Suda

Wael S. Al-lham

Forensic Laboratory, Gaza, Palestine

Corresponding Author:

Hazem M. Abu Shawish

e-mail: hazemona1@yahoo.co.uk

Submitted / Gönderilme: 17.08.2016 Accepted / Kabul: 22.09.2016

Revised / Düzeltme: 18.09.2016

\section{INTRODUCTION}

The ion selective electrode (ISE) is an indicator electrode capable of selectively measuring the activity of a particular ionic species (1). Potentiometric methods with ion-selective electrodes (ISEs) have proved to be effective for the analysis of pharmaceutical formulations and biological samples, because these sensors offer the advantages of simple design, construction, and manipulation, reasonable selectivity, fast response time, applicability to coloured and turbid solutions and possible interfacing with automated and computerized systems (2-7).

The construction of a polymeric membrane ion-selective electrode traditionally required a relatively high concentration of the ion of interest in the inner filling solution (IFS); however, experimental evidence suggested that this has a deteriorating influence on the detection limit (8). Mathison et al.(9) showed that an increased concentration of the primary ion in the inner solution leads to its extraction from there together with its counter ions forming ion fluxes from the membrane to the sample. This process changes the ion activity at the phase boundary thus significantly worsening the detection limit. 
Studies have shown the flux of ions from the membrane, in contact with the inner electrolyte solution that contains a salt of the primary ion, towards the sample causes the concentration in the contacting aqueous layer to be ca. $10^{-6}$ $\mathrm{mol} / \mathrm{L}$. Consequently, the lower detection limit was found to be around $10^{-6} \mathrm{~mol} / \mathrm{L}(10-12)$. Therefore, conventional ISEs must be well designed and miniaturized to sustain the need for portable devices, small samples, fast and cheap analysis that can be integrated into new devices with electronic control, measuring, and data acquisition units. All-solid-state potentiometric sensors provide an alternative as solid contact is formed between the sensing membrane and an electronconducting substrate to replace the liquid contact (13).

To shed light on this concept we have designed two new, a PVC-membrane and a graphite coated wire, electrodes and made a comparative study on their characterization.

Haloperidol, (4-[4-(4-chlorophenyl)-4-hydroxypiperidin-1yl]-1-(4-fluorophenyl)butan-1-one) (Figure 1), is an older antipsychotic used in the treatment schizophrenia and acute psychotic states and delirium. However, haloperidol produces extrapyramidal side effects including acute dystonic reactions, akathisia syndrome, drug induced parkinsonism, bradykinesia and tardive dyskinesia. Some research studies have suggested effects of haloperidol on brain tissue (14-16). Therefore, the determination of trace amounts of HP ion in biological fluids is necessary. Several analytical methods have been reported for the assay of haloperidol including capillary electrophoresis (17), acidimetric titration in non-aqueous medium (18), UV spectrophotometry (19-21), derivative spectrophotometry (22), colorimetry (23), H- nuclear magnetic resonance spectroscopy (24), densitometry (25), gas chromatography (GC) with electron-capture detection (26) GC with surface ionization detection (27), liquid chromatography (LC) with electrochemical detection (28), LC with UV detection (29), gas-LC with nitrogen-phosphorus detection $(30,31)$, LC with mass spectrometric (MS) detection $(32,33)$, high-performance liquid chromatography (HPLC) with diode array detection (34), HPLC with UV-VIS detection $(35,36)$, micellar electrokinetic chromatography (37), voltammetry (38) and potentiometry (3). These methods are highly sensitive. However, they did not allow the rapid quantification and identification of haloperidol in a one single run since most of these methods necessitate samples pretreatment and/or time consuming extraction steps prior to analysis of the drug. Besides, they are very expensive as they entail tedious sample manipulation, long analysis time as well as complex instrument setup hence becoming unsuitable for routine analysis. Consequently, there is a need for devising a selective, fast, accurate and inexpensive tool for determination of haloperidol drug.

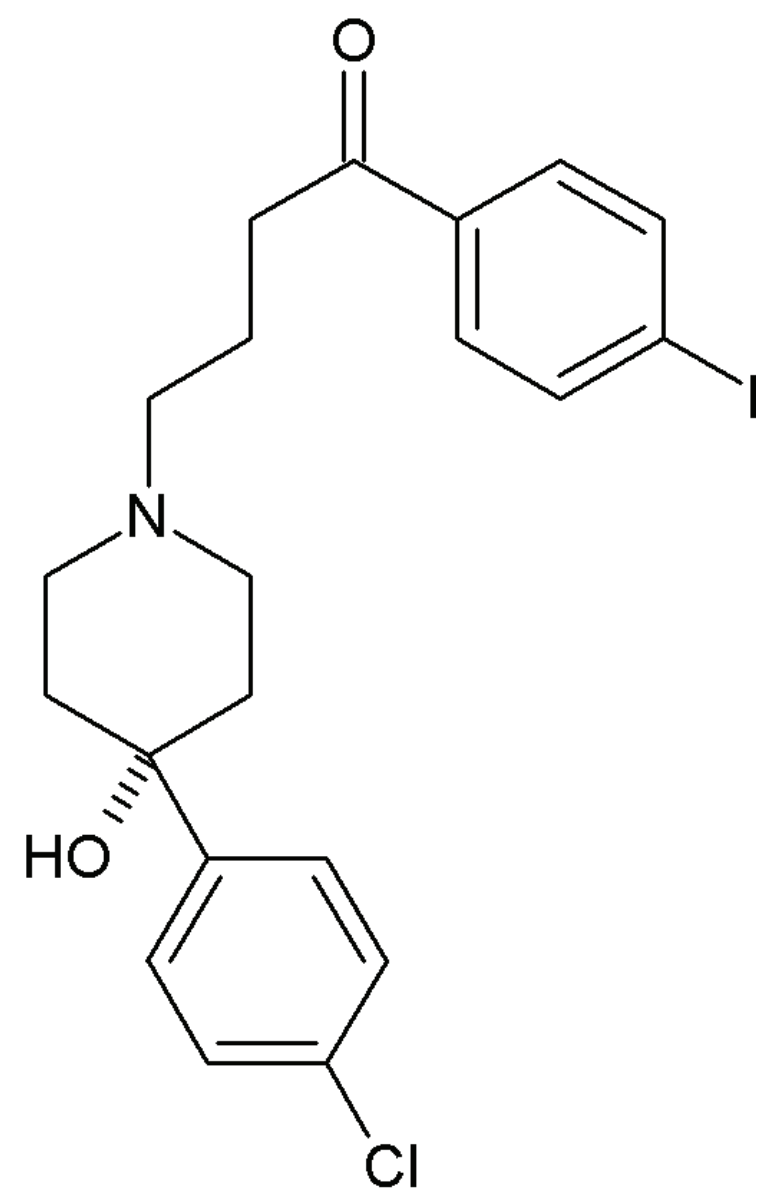

Figure 1. Chemical structure of haloperidol drug

Careful review of the literature spotted no polymeric membrane and coated wire ion-selective electrodes for determination of haloperidol drug and prompted exploration to design new types of electrodes for this purpose in continuation to our work on haloperidol analysis (3).

In this work, PVC-membrane and graphite coated sensors based on HP-PM as ion-pair dissolved in plasticizers dibutyl phthalate (DBP) and dioctyl phthalate (DOP) respectively were prepared, optimized, and checked at different concentration ranges for $\mathrm{HP}$ ions. The results showed that the graphite coated electrode surpass the PVC-membrane electrode. The electrodes exhibit a near Nernstian slope, wide concentration range, low detection limit and short response time. These electrodes were used successfully for the determination of drug ions in samples of ampoules and urine. 


\section{EXPERIMENTAL}

\section{Reagents}

Haloperidol drug (Ampoules $5 \mathrm{mg} / \mathrm{mL}$ ) were provided by the General Administration of Pharmacy Ministry of Health (Gaza-Palestine). The ampoule contains lactic acid and water for injection. Dibutyl phthalate (DBP), dioctyl phthalate (DOP) and tris(2-ethylhexyl) phosphate (DOPh) as well as metal salts were purchased from Sigma-Aldrich $(\mathrm{CH}-9471$ Buchs-Germany) and used as received. Phosphotungstic acid (PTA), phosphomolybdic acid (PMA), sodium tetraphenylborate (Na-TPB) Na, Poly(vinylchloride) (PVC) and tetrahydrofuran (THF) were obtained from SigmaAldrich (CH-9471 BuchsGermany). In addition, glucose, galactose, fructose, sucrose and all drugs were obtained from local drug stores.

\section{Apparatus}

Potentiometric and $\mathrm{pH}$ measurements were made with a Pocket $\mathrm{pH} / \mathrm{mV}$ Meters, $\mathrm{pH} 315 \mathrm{i}$ (WissenschaftlichTechnische Werkstatten GmbH (WTW), Weilheim, Germany). The saturated calomel electrode (SCE) was used as reference electrode for potential measurements. It was obtained from Sigma-Aldrich Co. (St Louis, MO, USA).

\section{Preparation of ion-pairs}

Two ion-pairs were made by mixing equal quantities of $1.0 \times 10^{-2} \mathrm{~mol} / \mathrm{L}$ of haloperidol and $3.3 \times 10^{-3} \mathrm{~mol} / \mathrm{L}$ of phosphotungstic acid or phosphomolybdic acid (39). The precipitates that formed were collected, intimately washed with distilled water, dried and ground to powders. The ionpair was utilized as a modifier for construction haloperidol sensors.

\section{Preparation of PVC membrane electrode}

The membranes were prepared according to a previously reported method (40). The membranes were prepared by dissolving different percentage of PVC, plasticizers and ion pairs in $5-10 \mathrm{~mL}$ of tetrahydrofuran (THF). The mixture was poured into a glass dish $7 \mathrm{~cm}$ in diameter. The THF was allowed to evaporate overnight leaving a transparent membrane. Small disks $(10 \mathrm{~mm})$ were punched from the cast films and mounted on home-made electrode bodies. The electrodes were filled with the internal filling solution ( $9 \mathrm{~mL}$ of $0.01 \mathrm{~mol} / \mathrm{L} \mathrm{KCl}$ and $1 \mathrm{~mL}$ of $0.001 \mathrm{~mol} / \mathrm{L} \mathrm{HP}$ ) and preconditioned by soaking for $5 \mathrm{~min}$ in $0.001 \mathrm{~mol} / \mathrm{L} \mathrm{HP}$ solution.

\section{Preparation of the coated-wire electrodes}

The coated-wire electrodes (CWEs) were prepared according to a previously reported method (41). The coating solution was prepared by dissolving 1.0\% HP-PM as ion-pair, 50.0\% PVC , $48.9 \%$ DOP as plasticizer and $0.1 \% \mathrm{Na}-\mathrm{TPB}$ as additive in $5.0 \mathrm{~mL}$ THF. A silver, copper and graphite wires about 1 $\mathrm{mm}$ diameter and $50 \mathrm{~mm}$ length were polished on a cloth pad and washed with acetone. One end of the wires were coated by repeated dipping into the mixture solution. A membranes were formed on the wire surface and was allowed to dry. The prepared electrodes were finally conditioned by soaking for 5 $\min$ in $0.001 \mathrm{M}$ of HP solution.

\section{Effect of interfering ions}

Potentiometric selectivity factors of the electrode were evaluated by applying the separate solution method (SSM) (42) and the modified separate solution method (MSSM) (43). In the SSM, the potential of a cell comprising a working electrode and a reference electrode is measured in two separate solutions, one containing the drug ions, $E_{D}$, and the other containing the interferent ions (J), $E_{J}$ and $\mathrm{S}$ is the slope of the calibration graph. $\mathrm{z}_{\mathrm{D}}$ and $\mathrm{z}_{\mathrm{J}}$ are the charge of HP and interfering species respectively. These values were used to calculate the selectivity coefficient from the following equation:

$$
\log K_{D, J^{z+}}^{\text {pot }}=\frac{\left(E_{J-} E_{D}\right)}{S}+\left(1-\frac{z_{D}}{z_{J}}\right) \log a_{D}
$$

In the modified separate solution method (MSSM), the potentiometric calibration curves are measured for the primary (I) and interfering ions (J). A plot of the measured potential vs. the concentration of ionic species, the drug or the interfering ion, is made from which the potential corresponding to $1.0 \mathrm{~mol} / \mathrm{L}$ concentration is obtained by extrapolation. The selectivity coefficients are calculated using Equation below.

$$
\log K_{D, J}^{p o t}=\frac{E_{J}^{0}-E_{D}^{0}}{S_{D}}
$$

Where $\log K_{D, J}^{\text {pot }}=$ selectivity coefficient; $E_{J}^{0}$ and $E_{D=}^{0}$ values from the extrapolated to $\log (\mathrm{a})=0$ calibration curves for various interfereing species and drug, for the studied electrode respectively; $S_{D}=$ slope of the drug electrode. 


\section{Determination of haloperidol in real samples}

\section{Potentiometric titration method}

Real samples $(5.0 \mathrm{~mL})$ of the drug ranging from $1.0 \times 10^{-3}$ $\mathrm{mol} / \mathrm{L}$ haloperidol in a $25-\mathrm{mL}$ beaker were potentiometricaly titrated with $1.0 \times 10^{-3} \mathrm{~mol} / \mathrm{L} \mathrm{Na-TPB}$ and the equivalence points were determined from the inverted S-shaped curve.

\section{Calibration graph method}

Different amounts of haloperidol comprising $4.2 \times 10^{-7} \mathrm{~mol} / \mathrm{L}$ to $1.0 \times 10^{-2} \mathrm{~mol} / \mathrm{L}$ of the drug were added to $50.0 \mathrm{~mL}$ of distilled water and the measured potential was recorded using the present electrodes. The potential was plot versus logarithm of the haloperidol activity and the resulting curve was used for determination of unknown drug concentration.

\section{Analysis of spiked urine samples}

Urine samples ranging $(0.5 \mathrm{~mL})$ were spiked with haloperidol and left stirred for $5 \mathrm{~min}$., transferred to a $25 \mathrm{~mL}$ volumetric flask and completed to volume to give $1.0 \times 10^{-6} \mathrm{~mol} / \mathrm{L}, 1.0 \mathrm{x}$ $10^{-5} \mathrm{~mol} / \mathrm{L}$ and $1.0 \times 10^{-4} \mathrm{~mol} / \mathrm{L}$ haloperidol. The drug-content of these solutions were determined by the calibration curve method.

\section{RESULTS AND DISCUSSION}

\section{Characteristics of the electrode}

It is a well-known fact that sensitivity, detection limit, linear range, and selectivity coefficients of ion-selective electrodes depend significantly on the nature of the utilized electrode active substance, the other components of the electrode as well as the properties of the plasticizer employed

\section{Effect of ion-pair}

The ion-pair has the main influence on the selectivity of the ISE membrane. The ion-pair was an ion-association complex of the drug cation with phosphotungstic acid (HP-PT) or phosphomolybdic acid (HP-PM) with different lipophilicities and stabilities. They were used as electroactive materials in PVC membrane and graphite coated wire electrodes. The experiments indicated that the electrodes containing (HP-PM) as an ion-pair gave the best results. Different compositions of HP-PM were prepared namely $0.5 \%, 1.0 \%, 2.0 \%$ and $3.0 \%(\mathrm{w} / \mathrm{w})$. The results show that the best sensitivity and linear range is attained at $3.0 \mathrm{wt} \%$ of the ion-pair for electrode $\mathrm{P}$ and $1.0 \%$ for electrode $\mathrm{g}$ as shown in (Table 1, electrode \#5) and (Table 2, electrode \#6). Further addition of the ion-pair resulted in a little decrease in the response of the electrodes that is most probably due to some inhomogenieties and possible saturation of the membrane as given in Table 2, electrode \#10 and 11 (32).

\section{Effect of lipophilic additives}

Lipophilic additives such as sodium tetraphenylborate reduce ohmic resistance and improve response behavior as well as the selectivity of the electrode in cases where the extraction capability of the ion-pair is poor. Comparison of the data, as shown in Table 2, for sensor g revealed that the slope of the calibration curve increased from 45.2 to $61.1 \mathrm{mV} /$ decade and the detection limits decreased From $2.2 \times 10^{-6}$ to $4.2 \mathrm{x}$ $10^{-7} \mathrm{~mol} / \mathrm{L}$ with the addition of a trace of Na-TPB (about 0.1 wt. \%).

\section{Plasticizer effect}

The membrane solvent reduces the viscosity and ensures a relatively high mobility of the membrane constituents. In order to provide a homogeneity of the organic phase it must be compatible with the other membrane components and acts as a plasticizer. Depending on its polarity and dielectric constant, it can influence the ion-exchanger characteristics of the membrane and, as a consequence, the selectivity (44).

To spot a suitable plasticizer for constructing the proposed two electrodes, we used three plasticizers, with various dielectric constants, as a measure of the molecular polarity, briefly: DOP $\left(\varepsilon_{\mathrm{r}}=5.1\right)$, DBP $\left(\varepsilon_{\mathrm{r}}=6.4\right)$ and DOPh $\left(\varepsilon_{\mathrm{r}}=4.8\right)$. The results obtained are shown in (Figure 2) Table 1 and Table 2, DBP and DOP as solvent mediators produced the best results for electrode $\mathrm{P}$ and $\mathrm{g}$ respectively. It is not clear why these mediators were the best among those used, but one can say that the outcome of their properties were the most effective on the electrode response. It is likely that DOP and DBP can extract haloperidol ions from aqueous solutions to the organic membrane phase.

Among the different compositions studied, the sensor containing 3.0\% HP-PM, 48.0\% PVC and 49.0\% DOP for sensor $\mathrm{P}$ and 1.0\% HP-PM, 50.0\% PVC, 48.9\% DBP and $0.1 \%$ of sodium tetraphenylborate (Na-TPB) for sensor $g$ exhibited the best response characteristics and the lowest detection limit. Therefore, these compositions were used to study various operation parameters of the electrodes. The electrochemical performance characteristics of this electrode were systematically evaluated according to the International Union of Pure and Applied Chemistry (IUPAC) recommendations (45). 

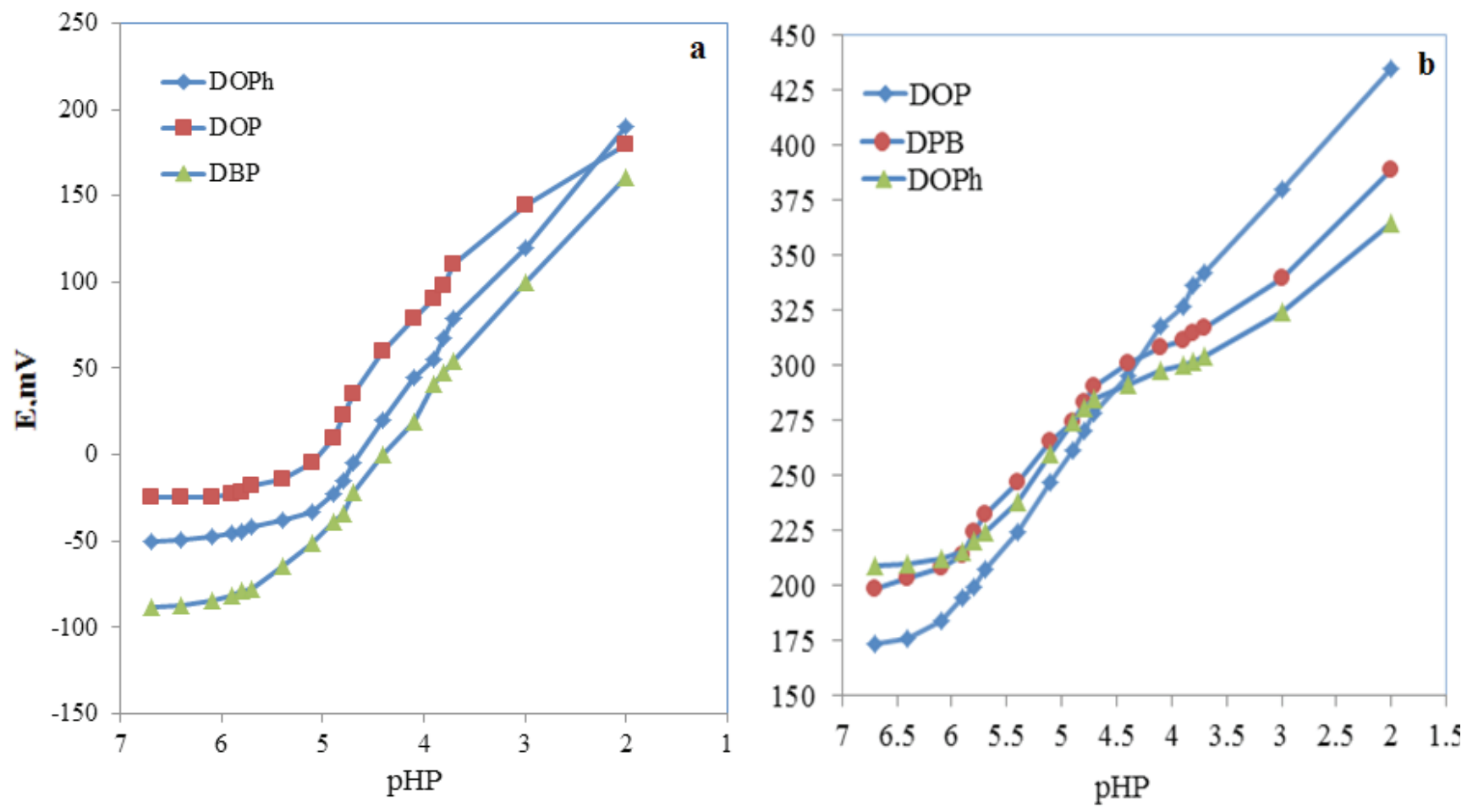

Figure 2. Effect of various plasticizers on the response of (a) electrode $\mathrm{P}$ and (b) electrode $g$

Table 1. Composition and slope of calibration curve for proposed P- electrode

\begin{tabular}{|c|c|c|c|c|c|c|c|c|}
\hline \multirow[t]{2}{*}{ No. } & \multicolumn{3}{|c|}{ Composition (\%) } & \multicolumn{5}{|c|}{ Electrode characteristics } \\
\hline & IP & PVC & $\mathbf{P}$ & $S$ & C.R & LOD & RSD & $\mathbf{R}(\mathbf{s})$ \\
\hline \multicolumn{9}{|c|}{ Influence of the amount of ion-pair } \\
\hline $1-$ & -- & 50.0 & $50.0 \mathrm{DBP}$ & $45.3 \pm 0.3$ & $2.7 \times 10^{-5}-1.0 \times 10^{-2}$ & $1.4 \times 10^{-5}$ & 1.79 & 25 \\
\hline $2-$ & $0.5 \mathrm{HD}-\mathrm{PM}$ & 49.3 & $50.2 \mathrm{DBP}$ & $50.2 \pm 0.7$ & $9.5 \times 10^{-6}-1.0 \times 10^{-2}$ & $8.1 \times 10^{-6}$ & 1.48 & 15 \\
\hline $3-$ & $1.0 \mathrm{HD}-\mathrm{PM}$ & 49.0 & $50.0 \mathrm{DBP}$ & $53.8 \pm 0.4$ & $8.7 \times 10^{-6}-1.0 \times 10^{-2}$ & $7.3 \times 10^{-6}$ & 1.39 & 12 \\
\hline $4-$ & $2.0 \mathrm{HD}-\mathrm{PM}$ & 48.5 & $49.5 \mathrm{DBP}$ & $55.8 \pm 0.5$ & $7.1 \times 10^{-6}-1.0 \times 10^{-2}$ & $6.1 \times 10^{-6}$ & 1.15 & 10 \\
\hline 5- & 3.0 HD-PM ${ }^{*}$ & 48.0 & $49.0 \mathrm{DBP}$ & $57.4 \pm 0.8$ & $3.7 \times 10^{-6}-1.0 \times 10^{-2}$ & $1.6 \times 10^{-6}$ & 1.12 & 5 \\
\hline \multicolumn{9}{|c|}{ Effect of different plasticizers } \\
\hline 6- & $3.0 \mathrm{HD}^{-\mathrm{PM}^{*}}$ & 48.0 & $49.0 \mathrm{DBP}$ & $57.7 \pm 0.8$ & $5.3 \times 10^{-6}-1.0 \times 10^{-2}$ & $4.1 \times 10^{-6}$ & 1.12 & 5 \\
\hline 7- & $3.0 \mathrm{HD}-\mathrm{PM}$ & 48.0 & $49.0 \mathrm{DOP}$ & $51.3 \pm 0.4$ & $9.1 \times 10^{-6}-1.0 \times 10^{-2}$ & $8.1 \times 10^{-6}$ & 1.78 & 8 \\
\hline $8-$ & $3.0 \mathrm{HD}-\mathrm{PM}$ & 48.0 & $49.0 \mathrm{DOPh}$ & $53.4 \pm 0.2$ & $6.5 \times 10^{-6}-1.0 \times 10^{-2}$ & $4.7 \times 10^{-6}$ & 1.27 & 5 \\
\hline \multicolumn{9}{|c|}{ Influence of the ion-pair } \\
\hline 9- & $3.0 \mathrm{HD}-\mathrm{PM}$ & 48.0 & $49.0 \mathrm{DBP}$ & $57.4 \pm 0.8$ & $3.7 \times 10^{-6}-1.0 \times 10^{-2}$ & $1.6 \times 10^{-6}$ & 1.12 & 5 \\
\hline $10-$ & $3.0 \mathrm{HD}-\mathrm{PT}$ & 48.0 & $49.0 \mathrm{DOP}$ & $48.1 \pm 0.3$ & $8.3 \times 10^{-6}-1.0 \times 10^{-2}$ & $7.1 \times 10^{-6}$ & 1.33 & 15 \\
\hline
\end{tabular}

IP: ion-pair PVC: poly vinyl chloride, P: plasticizer, S: slope (mV/decade), C.R.: concentration range, LOD: limit of detection, R(s): response time(s). ${ }^{\star}$ selected composition. 
Table 2. Optimization of membrane ingredients and their performance characteristics of g-electrode

\begin{tabular}{ccccccccc}
\hline & \multicolumn{3}{c}{ Composition (\%) } \\
No. $\begin{array}{c}\text { Kind of } \\
\text { wire }\end{array}$ & I.P & PVC & P & A & S & C.R. (M) & LOD(M) & R.S.D\%
\end{tabular}

\section{Effect of electrode bed}

3- graphite $1.0 \mathrm{HP}-\mathrm{PM}$

4- copper $\quad 1.0 \mathrm{HP}-\mathrm{PM}$

5- silver $\quad 1.0$ HP-PM

6- *graphite $1.0 \mathrm{HP}-\mathrm{PM}$

7- copper $\quad 1.0$ HP-PM
$50.0 \quad 49.0(\mathrm{DOP})$

50.0

50.0

50.0

50.0

50.0
49.0 (DOP)

49.0 (DOP)

48.9 (DOP)

48.9 (DOP)

48.9 (DOP)

$\begin{array}{llllll}- & 39.3 \pm 0.8 & 8.7 \times 10^{-6}-1.0 \times 10^{-2} & 7.1 \times 10^{-6} & 1.55 & 12 \\ - & 45.2 \pm 0.4 & 3.8 \times 10^{-6}-1.0 \times 10^{-2} & 2.2 \times 10^{-6} & 1.23 & 8 \\ - & 41.3 \pm 0.2 & 6.7 \times 10^{-6}-1.0 \times 10^{-2} & 3.8 \times 10^{-6} & 1.38 & 22 \\ 0.1 & 53.3 \pm 0.8 & 8.7 \times 10^{-7}-1.0 \times 10^{-2} & 6.5 \times 10^{-7} & 1.13 & 10 \\ 0.1 & 61.1 \pm 0.4 & 5.8 \times 10^{-7}-1.0 \times 10^{-2} & 4.2 \times 10^{-7} & 1.05 & 5 \\ 0.1 & 51.3 \pm 0.2 & 2.7 \times 10^{-6}-1.0 \times 10^{-2} & 1.6 \times 10^{-6} & 1.25 & 22\end{array}$

\section{Influence of the amount of ion-pair}

\begin{tabular}{|c|c|c|c|c|c|c|c|c|c|}
\hline 8- & graphite & -- & 50.0 & 49.4 (DOP) & 0.1 & $50.3 \pm 0.8$ & $5.6 \times 10^{-6}-1.0 \times 10^{-3}$ & $4.2 \times 10^{-6}$ & 1.58 \\
\hline 8- & graphite & 0.5 HP-PM & 50.0 & 49.4 (DOP) & 0.1 & $55.2 \pm 0.5$ & $7.8 \times 10^{-7}-1.0 \times 10^{-2}$ & $6.2 \times 10^{-7}$ & 1.22 \\
\hline 9- & graphite & $1.0 \mathrm{HP}-\mathrm{PM}$ & 50.0 & 48.9 (DOP) & 0.1 & $61.1 \pm 0.4$ & $5.8 \times 10^{-7}-1.0 \times 10^{-2}$ & $4.2 \times 10^{-7}$ & 1.05 \\
\hline $10-$ & graphite & 2.0 HP-PM & 49.0 & 48.9 (DOP) & 0.1 & $55.3 \pm 0.6$ & $7.2 \times 10^{-7}-1.0 \times 10^{-2}$ & $5.5 \times 10^{-7}$ & 1.10 \\
\hline $11-$ & graphite & 3.0 HP-PM & 48.7 & 48.2 (DOP) & 0.1 & $53.7 \pm 0.4$ & $5.8 \times 10^{-7}-1.0 \times 10^{-2}$ & $4.2 \times 10^{-7}$ & 1.34 \\
\hline
\end{tabular}

\section{Influence of the ion-pair}

\begin{tabular}{|c|c|c|c|c|c|c|c|c|}
\hline graphite & $1.0 \mathrm{HP}-\mathrm{PM}$ & 50.0 & 48.9 (DOP) & 0.1 & $61.1 \pm 0.4$ & $5.8 \times 10^{-7}-1.0 \times 10^{-3}$ & $4.2 \times 10^{-7}$ & 1.05 \\
\hline rraphite & $1.0 \mathrm{HP}-\mathrm{PT}$ & 50.0 & 48.9 (DOP) & 0.1 & $37.2 \pm 0.1$ & $1.7 \times 10-5-1.0 \times 10-3$ & $8.2 \times 10-6$ & 1.48 \\
\hline
\end{tabular}

\section{Effect of different plasticizer}

\begin{tabular}{|c|c|c|c|c|c|c|c|c|c|}
\hline $14-$ & graphite & $1.0 \mathrm{HP}-\mathrm{PM}$ & 50.0 & 48.9 (DOP) & 0.1 & $61.1 \pm 0.4$ & $5.8 \times 10^{-7}-1.0 \times 10^{-2}$ & $4.2 \times 10^{-7}$ & 1.05 \\
\hline $15-$ & graphite & 1.0 HP-PM & 50.0 & 48.9 (DBP) & 0.1 & $41.4 \pm 0.7$ & $1.5 \times 10^{-6}-2.6 \times 10^{-3}$ & $1.0 \times 10^{-6}$ & 1.77 \\
\hline 16 & graphite & 1.0 HP-PM & 50.0 & 48.9 (TEPh) & 0.1 & $38.6 \pm 0.3$ & $2.3 \times 10^{-6}-5.5 \times 10^{-3}$ & $1.2 \times 10^{-6}$ & 1.92 \\
\hline
\end{tabular}

\section{pH dependence}

The effect of $\mathrm{pH}$ on the response of the graphite coated wire and PVC membrane electrodes was examined in $1.0 \times 10^{-4}$ and $1.0 \times 10^{-5} \mathrm{~mol} / \mathrm{L} \mathrm{HP}$ solution in the $\mathrm{pH}$ range $2.5-11$. The $\mathrm{pH}$ was adjusted with dilute $\mathrm{HCl}$ or $\mathrm{NaOH}$ as required. It can be seen from (Figure 3) that the variation in potential due to $\mathrm{pH}$ change is considered acceptable in the $\mathrm{pH}$ range 2.5-7.5 for sensor $\mathrm{P}$ and 2.5-8.0 for g electrode. the potential decreases gradually at $\mathrm{pH}$ values higher than 7.5 and 8.0. The decrease may be attributed to hydroxide ions that react with HP leading to formation of free drug in the test solution, neutral species, which could not be extracted into the membrane.

\section{Effect of temperature}

To study the thermal stability of the electrodes, calibration graphs were constructed at different test solution temperatures of the test solution covering the range $20-55 \mathrm{C}$. The slope, response time, concentration range and the detection limit were obtained from the calibration plot corresponding to each temperature. It is obvious that no appreciable change in the calibration characteristics was observed in the temperature range. This indicates fairly high thermal stability of the electrodes. 

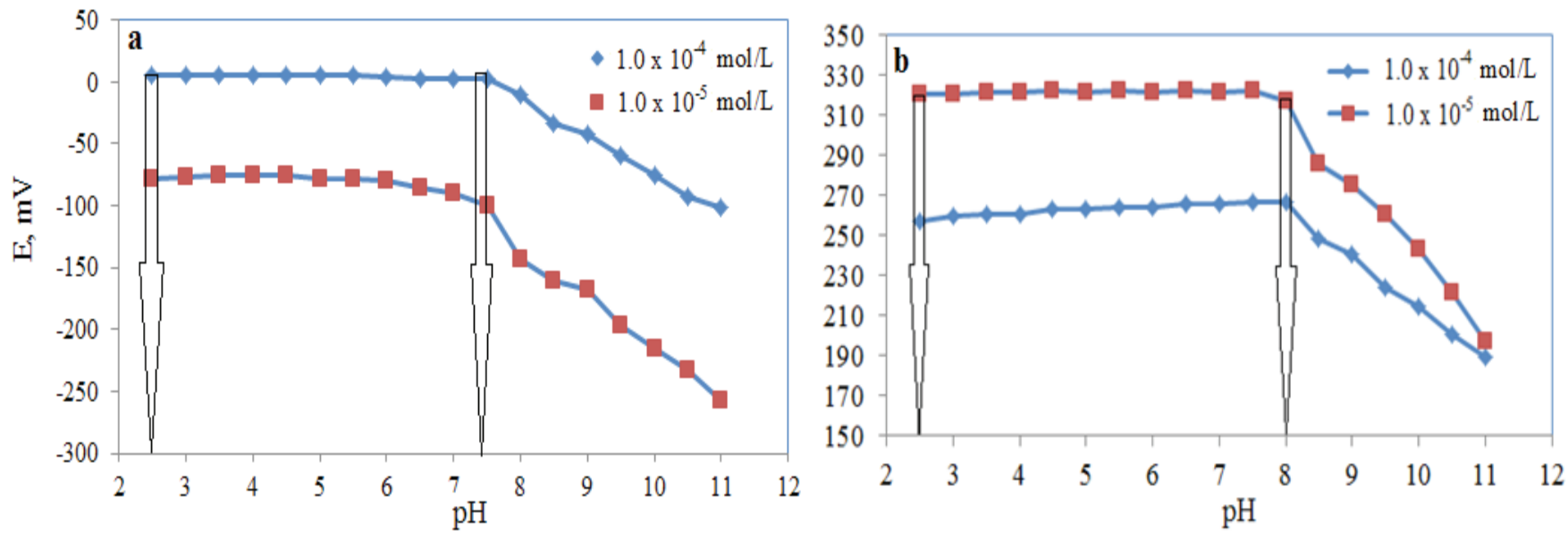

Figure 3. Influence of $\mathrm{pH}$ on the pesponce of (a) sensor $\mathrm{P}$ and (b) sensor $\mathrm{g}$

Dynamic response time, reversibility, life time repeatability and reproducibility of the electrodes

In this work, the response time was measured by varying the drug concentration over the range $1.0 \times 10^{-5} \mathrm{~mol} / \mathrm{L}$ to 1.0 $\times 10^{-2} \mathrm{~mol} / \mathrm{L}$ for sensor $\mathrm{P}$ and $1.0 \times 10^{-6} \mathrm{~mol} / \mathrm{L}$ to $1.0 \times 10^{-2}$ $\mathrm{mol} / \mathrm{L}$ for sensor $\mathrm{g}$. As shown in (Figure 4) the electrodes reach equilibrium in about $5 \mathrm{~s}$. The reversibility was evaluated by potential recording of the electrodes in the sequence high-to-low sample concentrations of HP drug. The results are shown in Fig. 4 and 5 indicate that the potentiometric responses of the sensors is reversible for proposed electrodes.

The effect of soaking time for each electrode was studied. The two electrodes were soaked in $1.0 \times 10^{-3} \mathrm{~mol} / \mathrm{L}$ solution of $\mathrm{HP}^{+}$. The optimum soaking time was found to be $15 \mathrm{~min}$. The calibration graphs were plotted after this period and their slopes were $57.4 \pm 0.7$ and $61.1 \pm 0.3 \mathrm{mV}$ per decade at $25^{\circ} \mathrm{C}$ for $\mathrm{P}$ and g electrodes respectively. The calibration plots slopes decreased to 53.4 and $55.3 \pm 0.1 \mathrm{mV} /$ decade after 28 days and one day for $\mathrm{P}$ and $\mathrm{g}$ sensors respectively.
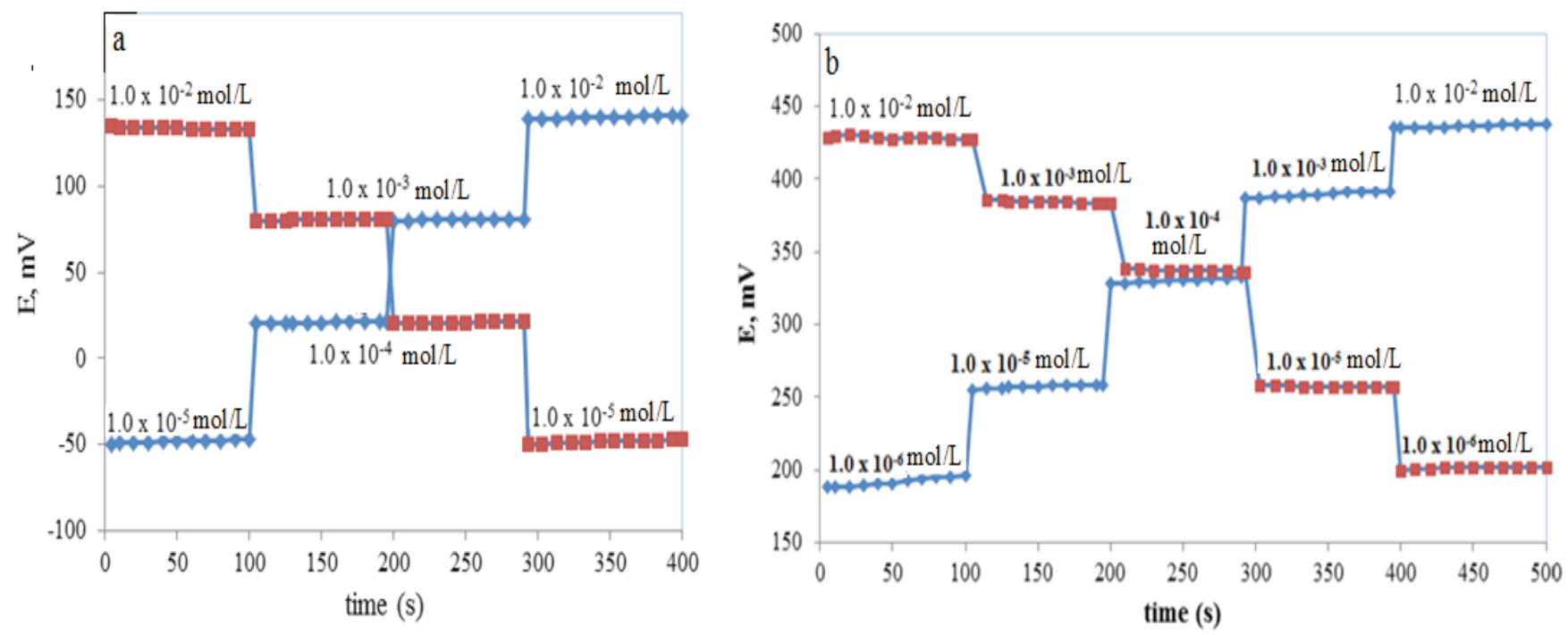

Figure 4. Dynamic response of (a) sensor P and (b) sensor g for step changes in concentration of HP drug (from low to high and vice versa) 

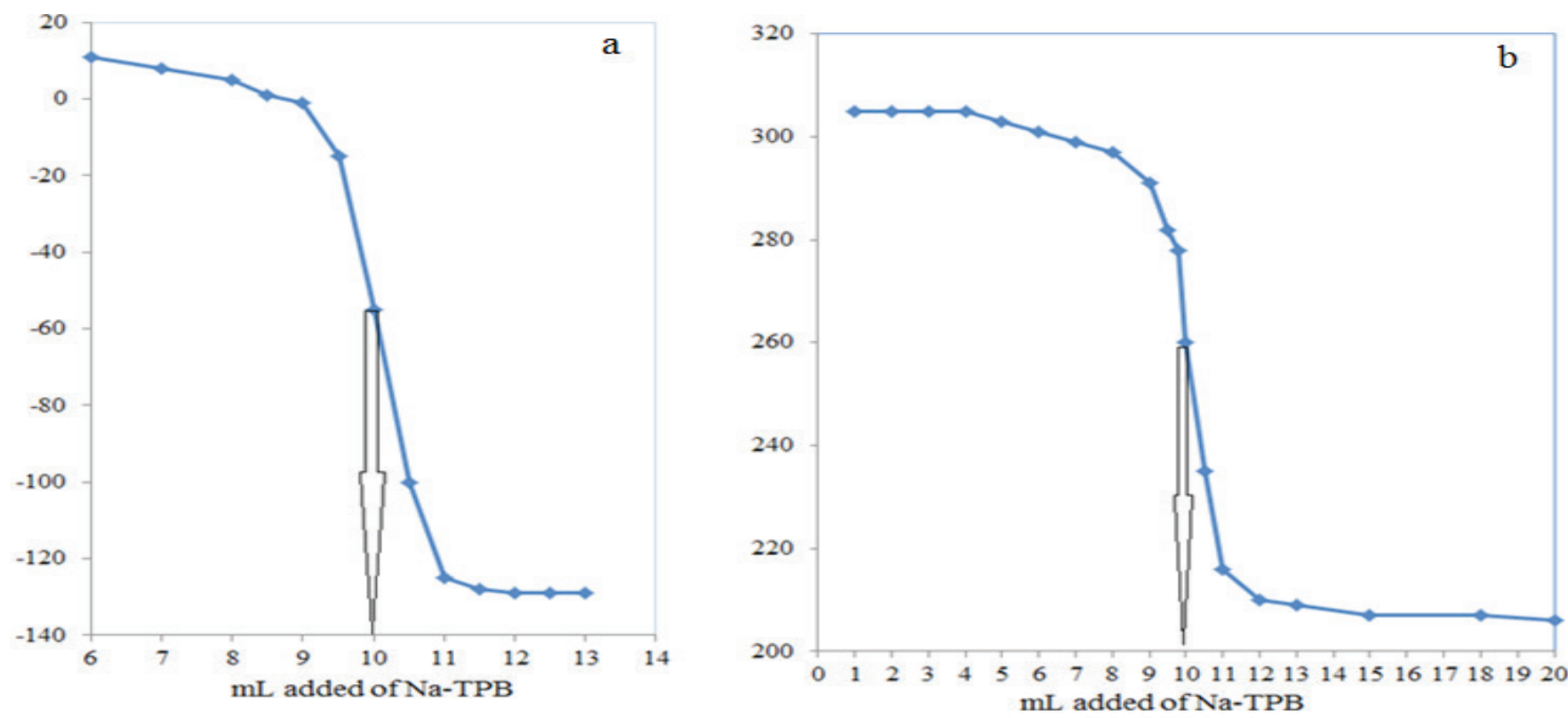

Figure 5. Potentiometric titration of $10 \mathrm{~mL}$ of $1.0 \times 10^{-3} \mathrm{~mol} / \mathrm{mL} \mathrm{HP}$ with $1.0 \times 10^{-3} \mathrm{mc} \mathrm{Na}-\mathrm{TPB}$ using (a) sensor P and (b) sensor $\mathrm{g}$

The reproducibility of the ion selective electrode is necessary for the observation of a similar response by another electrode prepared under similarly (46). To check this point, six independent sensors of $\mathrm{P}$ and sensors of $\mathrm{g}$ were made and tested into $5.0 \times 10^{-5} \mathrm{~mol} / \mathrm{L}$ solution. The proposed electrodes revealed good reproducibility with less than $1.85 \%$ standard deviation.

The repeatability of an ion-selective electrode describes its potential reusability over a definite period of time. Here, the $P$ electrode was tested for three consecutive days in which the electrode exhibited the similar response over the tested range of concentrations.

\section{Selectivity of the electrode}

The separate solution method (SSM) is recommended by IUPAC to determine the selectivity coefficient of the ISE (42). SSM is based on Nickolsky-Eisenman equation. However, it has been shown that this method suffers some limitations in terms of the values for ions of unequal charges, a non-Nernstain behavior of interfering ions (47). Therefore, an alternative approach is used, that is the modified separate solution method as described by Bakker et al. according to the following formula using the experimental slope (44). The resulting values, presented in Table 3 show that these sensors display significantly high selectivity for HP ions over many common organic and inorganic compounds, drugs, sugars, as well as some anions.

\section{Analytical applications}

In order to test the analytical applicability of the proposed sensors, they have been applied for determination of HP drug in ampoule and urine samples. Investigation were made in triplicate by the calibration curve methods. The results, in Table 4, show an average recovery of $100.5 \%$ with relative standard deviation (RSD) of $0.99 \%$ and indicate the utility of the proposed electrodes.

In addition, The electrodes of $\mathrm{P}$ and $\mathrm{g}$ were successfully applied as indicator electrodes in potentiometric titration of $5.0 \mathrm{~mL}$ of $1.0 \times 10^{-3} \mathrm{~mol} / \mathrm{L} \mathrm{HP}$ ion against $1.0 \times 10^{-2} \mathrm{~mol} / \mathrm{L}$ Na-TPB. The resulting titration curve is shown in (Figure 5). It is clear that the amount of HP ion can be an accurately determined with these electrodes.

\section{CONCLUSIONS}

PVC membrane and a graphite-coated wire electrodes were fabricated for determination of HP drug. They have attractive characteristics of high sensitivity, good selectivity, fast static response and a wide concentration range. Clearly, the a graphite-coated wire electrode shows a lower detection limit due to its diminished current flux. The proposed sensors offer the advantages of simplicity, accuracy, and applicability to turbid and colored solutions. 
Table 3. Selectivity coefficients of various interfering ions for $\mathrm{P}$ and g-electrodes

\begin{tabular}{|c|c|c|c|c|}
\hline \multirow{2}{*}{ Interfering ions } & \multicolumn{2}{|c|}{ Sensor P } & \multicolumn{2}{|c|}{ Sensor $\mathrm{g}$} \\
\hline & SSM & MSSM & SSM & MSSM \\
\hline $\mathrm{NH}_{+}^{+}$ & -3.23 & -3.41 & -3.13 & -3.51 \\
\hline $\mathrm{Na}^{4}$ & -3.25 & -3.64 & -3.01 & -3.33 \\
\hline $\mathrm{K}^{+}$ & -3.17 & -3.33 & -2.98 & -3.12 \\
\hline $\mathrm{Ca}^{2+}$ & -3.88 & -2.76 & -3.12 & -2.61 \\
\hline $\mathrm{Zn}^{2+}$ & -3.44 & -4.18 & -3.55 & -4.39 \\
\hline $\mathrm{Ni}^{2+}$ & -3.25 & -4.32 & -3.08 & -4.44 \\
\hline $\mathrm{Cd}^{2+}$ & -3.17 & -4.28 & -3.54 & -4.62 \\
\hline $\mathrm{Co}^{2+}$ & -3.24 & -4.15 & -3.10 & -4.29 \\
\hline $\mathrm{Cu}^{2+}$ & -3.54 & -2.68 & -3.24 & -2.44 \\
\hline glycine & --- & -3.42 & ---- & -3.31 \\
\hline asparagine & ---- & -4.06 & ---- & -4.23 \\
\hline arginine & --- & -4.21 & --- & -4.36 \\
\hline histidine & --- & -3.95 & ---- & -4.24 \\
\hline glucose & --- & -4.47 & ---- & -4.59 \\
\hline maltose & ---- & -4.79 & ---- & -4.88 \\
\hline galactose & --- & -4.55 & --- & -4.43 \\
\hline sucrose & --- & -4.41 & ---- & -4.45 \\
\hline diclofenac sodium (voltaren) & -3.66 & -3.86 & -3.32 & -3.55 \\
\hline ranitidine hydrochloride & -3.11 & -3.48 & -3.28 & -3.35 \\
\hline Metoclopramide hydrochloride & -3.25 & -3.42 & -3.96 & -3.72 \\
\hline ephedrine hydrochloride & -2.33 & -2.74 & -2.29 & -2.62 \\
\hline dapoxetine hydrochloride & -2.83 & -3.11 & -2.91 & -3.46 \\
\hline lidocaine hydrochloride & -3.35 & -3.16 & -3.28 & -3.21 \\
\hline atomoxetine hydrochloride & -2.87 & -3.02 & -2.77 & -3.22 \\
\hline amikacin sulfate & -3.17 & -3.33 & -3.24 & -3.14 \\
\hline tramadol hydrochloride & -2.53 & -2.83 & -2.75 & -2.91 \\
\hline duloxetine hydrochloride & -2.24 & -2.56 & -2.38 & -2.46 \\
\hline
\end{tabular}

Table 4. Analysis of HP drug in real samples using P and g sensors.

\begin{tabular}{|c|c|c|c|c|}
\hline samples & Taken (M) & Found (M) & $\mathrm{X} \%$ & R.S.D \% \\
\hline \multicolumn{5}{|l|}{$\frac{\text { Sensor } \mathbf{P}}{\text { ampoules }}$} \\
\hline & $1.00 \times 10^{-6}$ & $1.01 \times 10^{-6}$ & 101.0 & 1.17 \\
\hline & $1.00 \times 10^{-5}$ & $9.81 \times 10^{-6}$ & 98.1 & 1.02 \\
\hline & $1.00 \times 10^{-4}$ & $9.92 \times 10^{-5}$ & 99.2 & 0.76 \\
\hline \multicolumn{2}{|l|}{ urine } & $9.74 \times 10^{-6}$ & 97.4 & 1.08 \\
\hline & $1.00 \times 10^{-5}$ & $98.0 \times 10^{-6}$ & 98.0 & $\begin{array}{l}1.00 \\
1.23\end{array}$ \\
\hline & $1.00 \times 10^{-4}$ & $9.78 \times 10^{-5}$ & 97.8 & 1.55 \\
\hline \multicolumn{5}{|l|}{$\frac{\text { Sensor g }}{\text { ampoules }}$} \\
\hline & $1.00 \times 10^{-6}$ & $9.86 \times 10^{-7}$ & 98.6 & 1.28 \\
\hline & $1.00 \times 10^{-5}$ & $9.92 \times 10^{-6}$ & 99.2 & 0.89 \\
\hline & $1.00 \times 10^{-4}$ & $9.97 \times 10^{-5}$ & 99.7 & 0.64 \\
\hline \multicolumn{5}{|l|}{ urine } \\
\hline & $1.00 \times 10^{-6}$ & $1.01 \times 10^{-6}$ & 101.0 & 1.19 \\
\hline & $1.00 \times 10^{-5}$ & $9.84 \times 10^{-6}$ & 98.4 & 1.35 \\
\hline & $1.00 \times 10^{-4}$ & $9.92 \times 10^{-5}$ & 99.2 & 1.34 \\
\hline
\end{tabular}

R.S.D.: relative standard deviation, the number of replicate measurements $=4$; $\mathrm{X}$ : recovery

Potensiyometrik PVC-membran ve grafit kaplı tel elektrot yöntemiyle haloperidol'ün ampulde ve idrarda miktar tayini

\section{ÖZ}

Sensör P olarak isimlendirilen yeni bir PVC membran ve sensör G olarak isimlendirilen grafit kaplı tel Haloperidol'ün (HP) analizi için tanımlanmıştır. Elektrotlar P ve G için sırasıyla; Nernst denklemine göre en yüksek tepe noktası her onlu grup için $3.7 \times 10^{-6}-1.0 \times 10^{-2} \mathrm{~mol} / \mathrm{L}-5.8 \times 10^{-7}-1.0 \times 10^{-2} \mathrm{~mol} / \mathrm{L}$ deri- şim aralığında $57.4 \pm 0.8$ and $61.1 \pm 0.4 \mathrm{mV}$; deteksiyon alt sınırı (LOD) ise pH aralığ $2.5-7.5$ and 2.5-8.0 için $1.6 \times 10^{-6} \mathrm{~mol} / \mathrm{L}$ ve $4.2 \times 10^{-7} \mathrm{~mol} / \mathrm{L}$ olarak bulunmuştur. Tanımlanan sensörler HP'ün diğer gişim yapan bileşiklerden ayrılabilmesi için yüksek seçicilik göstermiştir. Bahsi geçen elektrotların kullanılmasıyla HP'ün ampül dozaj formundan ve idrar örneklerinden analizinin başarıyla yapılabileceği gösterilmiştir.

Anahtar kelimeler: Potensiyometri; Haloperidol; kaplanmış tel elektrot; PVC membrane elektrot; iyon-seçici elektrot. 


\section{REFERENCES}

1. Stradiotto NR, Yamanaka H, Zanoni MVB. Electrochemical sensors: a powerful tool in analytical chemistry. J Braz Chem Soc 2003;14:159-73.

2. Kulapina EG, Barinova OV. Ion-selective electrodes in drug analysis (A review). Pharm Chem J 1997;31:667-72.

3. Abu Shawish HM, Abed Almonem KI, Saadeh SM, Al-lham WS. Determination of haloperidol drug in ampoules and in urine samples using a potentiometric modified carbon paste electrode. Measurement 2016;78:180-6.

4. Khorshid AF, Issa YM. Modified carbon paste sensor for the potentiometric determination of neostigmine bromide in pharmaceutical formulations, human plasma and urine. Biosens Bioelectron. 2014;51:143-9.

5. Singh G, Rani S. Determination of promethazine in various pharmaceutical samples using promethazine selective poly(vinyl chloride) membrane electrode. J Adv Electrochem 2016;2:42-4.

6. Singhal B. Drug Analysis: A perspective of potentiometric sensors. World J Chem. 2011;6:59-74.

7. Kimmel DW, LeBlanc G, Meschievitz ME, Cliffel DE. Electrochemical sensors and biosensors. Anal Chem 2012;84:685-707.

8. Radu A, Meir AJ, Bakker E. Dynamic diffusion model for tracing the real-time potential response of polymeric membrane ion-selective electrodes. Anal Chem 2004;76:64029.

9. Mathison S, Bakker E. Effect of transmembrane electrolyte diffusion on the detection limit of carrier-based potentiometric ion sensors. Anal Chem 1998;70:303-9.

10. Rubinovan, Chumbimunitorres K, Bakker E. Solid-contact potentiometric polymer membrane microelectrodes for the detection of silver ions at the femtomole level. Sensors Actuators B Chem 2007;121:135-41.

11. Ceresa A, Bakker E, Hattendorf B, Günther D, Pretsch E. Potentiometric polymeric membrane electrodes for measurement of environmental samples at trace levels: New requirements for selectivities and measuring protocols, and comparison with ICPMS. Anal Chem 2001;73:343-51.

12. Pretsch E. The new wave of ion-selective electrodes. TrAC Trends Anal Chem [Internet]. 2007;26:46-51.

13. Lindner E, Gyurcsányi RE. Quality control criteria for solidcontact, solvent polymeric membrane ion-selective electrodes. J Solid State Electrochem 2009;13:51-68.

14. Hu J, Stein A, Bühlmann P. Rational design of all-solid-state ion-selective electrodes and reference electrodes. TrAC Trends Anal Chem 2016;76:102-14.

15. Giannini AJ, Underwood NA, Condon M. Acute ketamine intoxication treated by haloperidol: a preliminary study. Am J Ther 2000;7:389-91.

16. Dorph-Petersen K-A, Pierri JN, Perel JM, Sun Z, Sampson AR, Lewis DA. The influence of chronic exposure to antipsychotic medications on brain size before and after tissue fixation: A comparison of haloperidol and olanzapine in macaque monkeys. Neuropsychopharmacol 2005 9;30:1649-61.

17. Wu S-M, Ko W-K, Wu H-L, Chen S-H. Trace analysis of haloperidol and its chiral metabolite in plasma by capillary electrophoresis. J Chromatogr A 1999;846:239-43.
18. Demoen PJAW. Properties and analysis of haloperidol and its dosage forms. J Pharm Sci [Internet] 1961;50:350-3.

19. Marzanna Kurzawa AK-MES. Conductometric and spectrophotometric determination of haloperidol, droperidol and pimozide. Chem Analityczna 2004;49:91-9.

20. Yasir M, Sara UVS. Development and validation of UV spectrophotometric method for the estimation of haloperidol. Br J Pharm Res 2014;4:1407-15.

21. British Pharmacopoeia, Vol. II. Her Majesty's Stationery Office, London. 1993.

22. Ouanês S, Kallel M, Trabelsi H, Safta F, Bouzouita K. Zerocrossing derivative spectrophotometry for the determination of haloperidol in presence of parabens. J Pharm Biomed Anal 1998;17:361-4.

23. Janicki CA, Almond HR. Reaction of Haloperidol with 5-(Hydroxymethyl)-2-furfuraldehyde, an Impurity in Anhydrous Lactose. J Pharm Sci 1974;63:41-3.

24. Shamsipur M, Shafiee-Dastgerdi L, Talebpour Z, Haghgoo S. 19F NMR as a powerful technique for the assay of anti-psychotic drug haloperidol in human serum and pharmaceutical formulations. J Pharm Biomed Anal 2007;43:1116-21.

25. Krzek J, Maślanka A. Densitometric determination of impurities in pharmaceuticals. Part VI. Determination of 4,4-bis[4-(p-chlorophenyl)- 4-hydroxypiperidino] butyrophenone in haloperidol. Acta Pol Pharm 57:23-6.

26. Zingales IA. A gas chromatographic method for the determination of haloperidol in human plasma. J Chromatogr A 1971;54:15-24.

27. Fujii T, Hatanaka K, Sato G, Yasui Y, Arimoto H, Mitsutsuka Y. Selective determination of haloperidol in human serum: surface ionization mass spectrometry and gas chromatography with surface ionization detection. J Chromatogr B Biomed Appl 1996;687:395-403.

28. Bagheri H, Afkhami A, Panahi Y, Khoshsafar H, Shirzadmehr A. Facile stripping voltammetric determination of haloperidol using a high performance magnetite/carbon nanotube paste electrode in pharmaceutical and biological samples. Mater Sci Eng C 2014;37:264-70.

29. Nilsson LB. Reversed-phase ion-pair liquid chromatographic method for the determination of low concentrations of haloperidol in plasma. J Chromatogr B Biomed Sci Appl 1988;431:113-22.

30. Abernethy DR, Greenblatt DJ, Ochs HR, Willis CR, Miller DD, Shader RI. Haloperidol determination in serum and cerebrospinal fluid using gas-liquid chromatography with nitrogen-phosphorus detection: Application to pharmacokinetic studies. J Chromatogr B Biomed Sci Appl 1984;307:194-9.

31. Bianchetti G, Morselli PL. Rapid and sensitive method for determination of haloperidol in human samples using nitrogen-phosphorus selective detection. J Chromatogr A 1978 Jun;153:203-9.

32. Arinobu T, Hattori H, Iwai M, Ishii A, Kumazawa T, Suzuki O, Seno H. Liquid chromatographic-mass spectrometric determination of haloperidol and its metabolites in human plasma and urine. J Chromatogr B 2002;776:107-13.

33. Titier K, Bouchet S, Péhourcq F, Moore N, Molimard M. Highperformance liquid chromatographic method with diode array detection to identify and quantify atypical antipsychotics and 
haloperidol in plasma after overdose. J Chromatogr B Analyt Technol Biomed Life Sci 2003;788:179-85.

34. Ebrahimzadeh H, Dehghani Z, Asgharinezhad AA, Shekari N, Molaei K. Determination of haloperidol in biological samples using molecular imprinted polymer nanoparticles followed by HPLC-DAD detection. Int J Pharm 2013;453:601-9.

35. Park KH, Lee MH, Lee MG. Simultaneous determination of haloperidol and its metabolite, reduced haloperidol, in plasma, blood, urine and tissue homogenates by high-performance liquid chromatography. J Chromatogr B Biomed Sci Appl 1991; 572:259-67.

36. Yasui-Furukori N, Inoue Y, Chiba M, Tateishi T. Simultaneous determination of haloperidol and bromperidol and their reduced metabolites by liquid-liquid extraction and automated column-switching high-performance liquid chromatography. J Chromatogr B 2004;805:175-80.

37. Driouich R, Takayanagi T, Oshima M, Motomizu S. Separation and determination of haloperidol, parabens and some of their degradation products by micellar electrokinetic chromatography. J Chromatogr A 2000;903:271-8.

38. El-Desoky HS, Ghoneim MM. Assay of the anti-psychotic drug haloperidol in bulk form, pharmaceutical formulation and biological fluids using square-wave adsorptive stripping voltammetry at a mercury electrode. J Pharm Biomed Anal 2005;38:543-50.

39. Khedr AM, Abu Shawish HM, Gaber M, Abed Almonem KI. Potentiometric determination of alkyl dimethyl hydroxyethyl ammonium surfactant by a new chemically modified carbon past electrode. J Surfactants Deterg 2014;17:183-90.

40. Abu Shawish HM, Khedr AM, Abed-Almonem KI, Gaber
M. A comparative study of solid and liquid inner contact benzalkonium chloride ion-selective electrode membranes. Talanta 2012;101:211-9.

41. Abu Shawish HM, Saadeh SM, Tamos H, Abed-Almonem KI, Khalili OA. A novel coated silver ketamine(I) electrode for potentiometric determination of ketamine hydrochloride in ampoules and urine samples. Anal Chem Res 2014;2:30-6.

42. Lindner E, Umezawa Y. Performance evaluation criteria for preparation and measurement of macro- and microfabricated ion-selective electrodes (IUPAC Technical Report). Pure Appl Chem 2008;80:85-104.

43. Bakker E, Pretsch E, Bühlmann P. Selectivity of potentiometric ion sensors. Anal Chem 2000;72:1127-33.

44. Ceresa A, Bakker E, Hattendorf B, Günther D, Pretsch E. Potentiometric polymeric membrane electrodes for measurement of environmental samples at trace levels: New requirements for selectivities and measuring protocols, and comparison with ICPMS. Anal Chem 2001;73:343-51.

45. Buck RP, Lindner E. Recommendations for nomenclature of ionselective electrodes (IUPAC Recommendations 1994). Pure Appl Chem 1994;66:2527-36.

46. Ibupoto Z, Khun K, Willander M. A selective iodide ion sensor electrode based on functionalized $\mathrm{ZnO}$ nanotubes. Sensors 2013;13:1984-97.

47. Chandra S, Agarwal H, Singh CK. A Highly selective and sensitive thorium(IV) PVC membrane electrode based on a dithio-tetraaza macrocyclic compound. Anal Sci 2007;23:46973. 